\title{
Investigation of Crystallization and Microstructure of $\mathrm{Na}_{2} \mathrm{O}-\mathrm{CaO}-\mathrm{P}_{2} \mathrm{O}_{5}-\mathrm{SiO}_{2}-\mathrm{Al}_{2} \mathrm{O}_{3}$ Bio Glass Ceramic System
}

\author{
Bahman Mirhadia ${ }^{1}$, Behzad Mehdikhanib ${ }^{2 *}$ \\ ${ }^{1}$ Engineering Department, Imam Khomeini International University, Qavin, Iran; ${ }^{2}$ Ceramic Department, Standard Research Institute, \\ Karaj, Iran. \\ Email: "mehdikhani@standard.ac.ir,mirhadi@ikiu.ac.ir
}

Received September $15^{\text {th }}$, 2011; revised October $25^{\text {th }}, 2011$; accepted November $3^{\text {rd }}, 2011$

\begin{abstract}
The effects of $\mathrm{Al}_{2} \mathrm{O}_{3}$ on the crystallization behavior of glass compositions in the $\mathrm{Na}_{2} \mathrm{O}-\mathrm{CaO}-\mathrm{P}_{2} \mathrm{O}_{5}-\mathrm{SiO}_{2}$ system were investigated by differential thermal analysis (DTA), X-ray diffraction (XRD) and scanning electron microscopy (SEM). In this system, thermal parameters of glasses were studied by DTA. The density of the glass ceramic samples was measured by Archimedes' method. It was found that the glass-ceramic containing 2.0 molar percent $\mathrm{Al}_{2} \mathrm{O}_{3}$ had desirable sintering behavior and reached to an acceptable density. Phase investigation and micro structural study were performed by XRD and SEM, respectively.
\end{abstract}

Keywords: Bio Glass-Ceramic; Alumina; Crystallization; Mechanical Behavior

\section{Introduction}

Bioglasses can be classified by chemical compositions which include $\mathrm{SiO}_{2}, \mathrm{CaO}$ and $\mathrm{P}_{2} \mathrm{O}_{5}, \mathrm{Na}_{2} \mathrm{O}, \mathrm{K}_{2} \mathrm{O}, \mathrm{MgO}$, $\mathrm{Al}_{2} \mathrm{O}_{3}, \mathrm{CaF}_{2}, \mathrm{~B}_{2} \mathrm{O}_{3}$ and other compositions as optional [1-4]. The main bioactive glasses, glass-ceramics and ceramics used clinically are bio glass in the system $\mathrm{Na}_{2} \mathrm{O}-\mathrm{CaO}-\mathrm{P}_{2} \mathrm{O}_{5}-\mathrm{SiO}_{2}$ hydroxyapatite $\left(\mathrm{Ca}_{10}\left(\mathrm{PO}_{4}\right)_{6}(\mathrm{OH})_{2}\right)$, tricalcium Phosphate $\mathrm{Ca}_{3}\left(\mathrm{PO}_{4}\right)_{2}, \mathrm{HA} / \mathrm{TCP}$ of different phases, ceramics and glass-ceramics, $\mathrm{A} / \mathrm{W}$ containing crystalline oxyfluoroapatite $\left[\left(\mathrm{Ca}_{10}\left(\mathrm{PO}_{4}\right)_{6} \mathrm{O}, \mathrm{F}\right)\right.$ and wollastonite $\left(\mathrm{CaSiO}_{3}\right)$ in $\mathrm{MgO}-\mathrm{CaO}-\mathrm{SiO}_{2}$ glassy matrix $[5,6]$. $\mathrm{Na}_{2} \mathrm{O}-\mathrm{CaO}-\mathrm{P}_{2} \mathrm{O}_{5}-\mathrm{SiO}_{2}$ glass ceramic is a commercially available inorganic material, which has been used as bone replacement for more than 20 years [1]. This is the first bioactive glass developed by Hench et al. in 1969 [7]. They are excellent biomaterials because they are nontoxic, they match the composition of natural bone, and show excellent integration with bone in the framework of in vitro and in vivo studies. Unfortunately, the low toughness of bioactive glass has limited its use to non-load-bearing applications [8,9]. Crystallization of bioactive glasses may be the best way to improve their mechanical properties $[8,10,11]$. It has been reported [12] that some glass-ceramics in the $\mathrm{Na}_{2} \mathrm{O}-\mathrm{CaO}-\mathrm{P}_{2} \mathrm{O}_{5}-\mathrm{SiO}_{2}$ system, containing apatite and wollastonite phases, with good mechanical properties and the ability of forming tight chemical bonds with living bone can be produced

*Corresponding author. through sintering and subsequent crystallization of glass powders. The effect of compositional changes on the bioactivity [13] and the crystallization behavior of some glass-ceramics located in certain compositional regions of the system have also been investigated [14]. The addition of a network former oxide like $\mathrm{Al}_{2} \mathrm{O}_{3}$ reduces the glass dissolution compare to other bioactive glasses. This lower dissolution and the lower release in aluminum lead to the formation of the $(\mathrm{Si}, \mathrm{O}, \mathrm{Al})$ layer. On the other hand, addition of network formers could significantly reduce the bioactivity of the material because the ability to form an apatite is reduced as the ionic field strength increases. This is not the case with $2.0 \mathrm{~mol} \%$ of $\mathrm{Al}_{2} \mathrm{O}_{3}$, in our study there is the formation of a (Ca, P) rich layer [15]. The main objective of the present investigation is to study the effect of $\mathrm{Na}_{2} \mathrm{O}$ replacement by $\mathrm{P}_{2} \mathrm{O}_{5}$ on the hardness of the above mentioned glass-ceramics. The effect of these composition changes on the crystallization behavior of these materials, in relation to their mechanical properties was also investigated.

\section{Experimental}

The glass of $\mathrm{Na}_{2} \mathrm{O}-\mathrm{CaO}-\mathrm{P}_{2} \mathrm{O}_{5}-\mathrm{SiO}_{2}$ was prepared by the melt quench technique. The glass compositions in the mol\% are given in Table 1. The glass batches were prepared from reagent grade powders: calcium carbonate $\left(\mathrm{CaCO}_{3}, 100 \%\right)$, quartz $\left(\mathrm{SiO}_{2}, 99.9 \%\right)$ and sodium carbonate $\left(\mathrm{Na}_{2} \mathrm{CO}_{3}, 99.98 \%\right),\left(\left(\mathrm{NH}_{4}\right)_{2} \mathrm{HPO}_{4}, 99.8 \%\right)$, Alumina $\left(\mathrm{Al}_{2} \mathrm{O}_{3}, 99.9 \%\right)$. The amounts of oxides were 
Table 1. Nominal glass compositions (mol\%).

\begin{tabular}{cccccc}
\hline Sample NO. & $\mathrm{P}_{2} \mathrm{O}_{5}$ & $\mathrm{CaO}$ & $\mathrm{SiO}_{2}$ & $\mathrm{Na}_{2} \mathrm{O}$ & $\mathrm{Al}_{2} \mathrm{O}_{3}$ \\
\hline $\mathrm{G} 0$ & 6 & 24.5 & 45 & 24.5 & 0 \\
$\mathrm{G} 1$ & 6 & 24.5 & 45 & 24.0 & 0.5 \\
$\mathrm{G} 2$ & 6 & 24.5 & 45 & 23.5 & 1.0 \\
$\mathrm{G} 3$ & 6 & 24.5 & 45 & 22.5 & 2.0 \\
\hline
\end{tabular}

weighed by using digital electronic balance. The chemical were then mixed in a pestle mortal. The mixed powder of these samples were placed in recrystallized alumina crucible and melted in an electrically heated furnace. The powder of the samples were initially kept at $1000^{\circ} \mathrm{C}$ for 1 hour for calcination to occur and release of water from the starting materials then they were reheated at $1550^{\circ} \mathrm{C}$ and kept at this temperature for half an hour in order to achieve the homogeneity. Melted glasses were poured into cold water and, after grinding they were remelted. After the second melting a portion of the melt was poured into water to obtain frit and milled up frit to obtain a powder glass with particle size smaller than 30 $\mu \mathrm{m}$. Particle size distributions of glass powders were characterized by a laser particle size analyzer Fritsch analyses 22. Glass powders with $0.2 \mathrm{wt} \%$ carboxy methyl cellulose (CMC) water solution (based on dried frit weight) were uniaxially pressed at $30 \mathrm{MPa}$ and were shaped in a $20 \mathrm{~mm}$ cylindrical die. The obtained compacts were then sintered in an electric laboratory furnace at their crystallization temperature for 3 hour. For firing the samples a constant heating rate of $7^{\circ} \mathrm{C} / \mathrm{min}$ and a soaking time of 1 hour were used and then the furnace was allowed to cool down. The soaking time was 3 hour. The hardness was measured by Rockwell (switzerland model ROC 190). The densities of the resulting glass ceramics were measured via Archimedes's method.

\subsection{Thermal Measurements}

The thermal behavior of glasses was monitored by DTA scans which were carried out using a simultaneous thermal analyzer (Polymer Laboratories STA-1640). Platinum containers were used for both the glass and the reference samples in air static atmosphere. The DTA equipment was calibrated periodically using $\mathrm{Na}_{2} \mathrm{SO}_{4}$ as a standard at the same conditions used for the samples measurements. The data were recorded and analysed in a computer interfaced with the DTA equipment. The error in the determination of the maximum position is due primarily to the accuracy of the DTA, which is $\pm 2^{\circ} \mathrm{C}$.

\subsection{X-Ray Diffraction (XRD) and Microscopic Examinations}

In order to determine the crystallisation products, the heat-treated samples were subjected to XRD analysis (Siemens, D-500) using $\mathrm{Cu}(\mathrm{K} \alpha)$ radiation at $40 \mathrm{kV}$ and $20 \mathrm{~mA}$ setting and in $2 \theta$ range from $5^{\circ}$ to $70^{\circ}$. Information concerning the mechanism of crystallisation and the microstructure of the glass ceramic materials were obtained by a SEM (VEGA-TESCAN), on superficially polished gold-coated specimens. Energy dispersion X-ray spectroscopy, EDS, was used to identify the chemical composition of the different phases in the samples.

\section{Results}

\subsection{Differential Thermal Analysis (DTA)}

Typical DTA of the samples crystallized at the heating rate of $10^{\circ} \mathrm{C} / \mathrm{min}$ are shown in Figure 1, and Table 2, for different bio glasses samples. The results revealed that the crystallization temperature increased with increasing $\mathrm{Al}_{2} \mathrm{O}_{3}$. When aluminium ion substituted for sodium ions the bonds are formed with the strong covalent $\mathrm{Al}-\mathrm{O}$ bond than $\mathrm{Na}-\mathrm{O}$ because of the electronegativity of aluminium is higher than sodium. The increasing of crystallization temperature with increasing of $\mathrm{Al}_{2} \mathrm{O}_{3}$ content related due to the stronger bonding in to the glass structure.

\subsection{Density}

Results presented in Figure 2 show that the density increases with increasing $\mathrm{Al}_{2} \mathrm{O}_{3}$ in the glass. Samples have been sintered at their crystallization temperature. This is due to presence of $\mathrm{Al}_{2} \mathrm{O}_{3}$ provide more density than $\mathrm{Na}_{2} \mathrm{O}$. This indicates that replacement of $\mathrm{Na}^{+}$ion by $\mathrm{Al}^{3+}$ ion increase the density of glass. With comparison of density

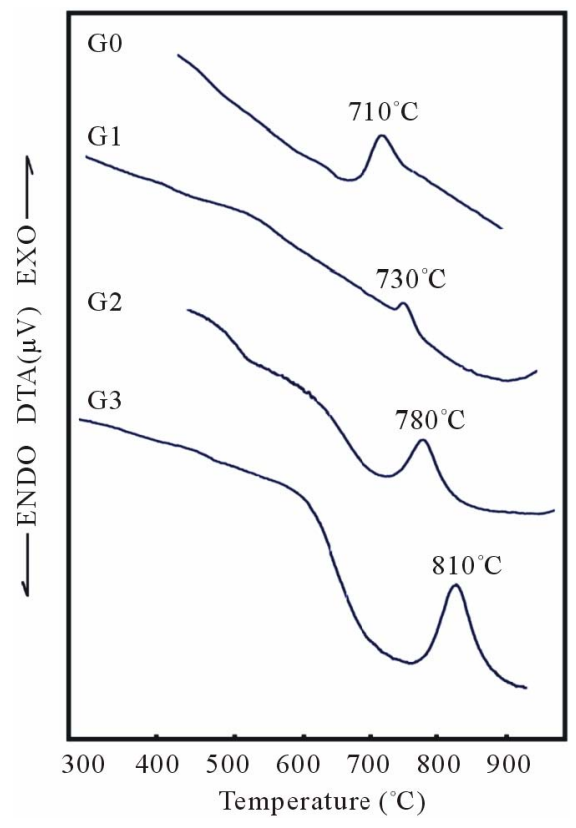

Figure 1. Variation crystallization temperature with increases of $\mathrm{Al}_{2} \mathrm{O}_{3}$ content of bioglass samples. 
Table 2. Crystallization peak temperatures of bioglass samples with increase of $\mathrm{Al}_{2} \mathrm{O}_{3}$.

\begin{tabular}{cc}
\hline Samples & $\mathrm{T}_{\mathrm{C}}\left({ }^{\circ} \mathrm{C}\right)$ \\
\hline G0 & 710 \\
G1 & 730 \\
G2 & 780 \\
G3 & 810 \\
\hline
\end{tabular}

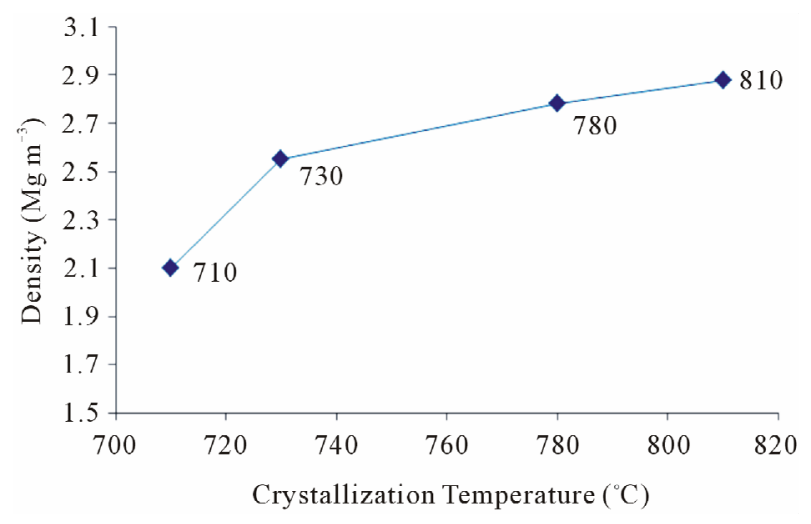

Figure 2. Variation of density with increase of $\mathrm{Al}_{2} \mathrm{O}_{3}$ content of bioglass samples.

results and crystallization peak temperature of each glass, it can be concluded that sample G3 reaches to maximum densification.

\subsection{X-Ray Diffraction Results for Bio Glass-Ceramics}

Phase formation study of G3 sample sintered at $800^{\circ} \mathrm{C}$, $850^{\circ} \mathrm{C}$ and $900^{\circ} \mathrm{C}$ was carried out by XRD. The XRD patterns of this composition with various sintering temperature are shown in Figure 3. It can be seen that all sintered temperatures have amorphous phase coexist with some crystal phases. The X-ray diffraction analysis of G3, sintered at $800^{\circ} \mathrm{C}$ (Table 3, Figure 3), showed that wollastonite- $\mathrm{CaSiO}_{3}$ was crystallized as a major phase together with Sodium Phosphate $\mathrm{NaPO}_{3}$.

Increasing sintering temperature up to $850^{\circ} \mathrm{C}$ cause that the peaks of the $\mathrm{NaPO}_{3}$ phase are seen to be disappeared and new peaks of $\mathrm{NaCaPO}_{4}, \mathrm{CaP}_{2} \mathrm{O}_{6}, \mathrm{CaAl}_{2} \mathrm{Si}_{2} \mathrm{O}_{8}$ and $\mathrm{NaAlSiO}_{4}$ phases are distinguished, this effect may be controlled with assumption of the depolymerization effect on the metaphosphate network. The XRD analysis of G3 sintered at $900^{\circ} \mathrm{C}$ showed that, Wollastonite $\mathrm{CaSiO}_{3}$, Sodium Calcium Phosphate $\mathrm{Ca}_{10} \mathrm{Na}\left(\mathrm{PO}_{4}\right)_{7}$ and Sodium Calcium Silicate $\mathrm{Na}_{4} \mathrm{CaSi}_{3} \mathrm{O}_{9}, \mathrm{CaAl}_{2} \mathrm{Si}_{2} \mathrm{O}_{8}$ and $\mathrm{NaAlSi}_{3} \mathrm{O}_{8}$ Phases are formed. Sodium Calcium Phosphate $\mathrm{NaCaPO}_{4}$ crystal is analyzed as primary crystal after sintering at $850^{\circ} \mathrm{C}$ for $3 \mathrm{~h}$. XRD investigations showed the precipitation of an additional crystalline

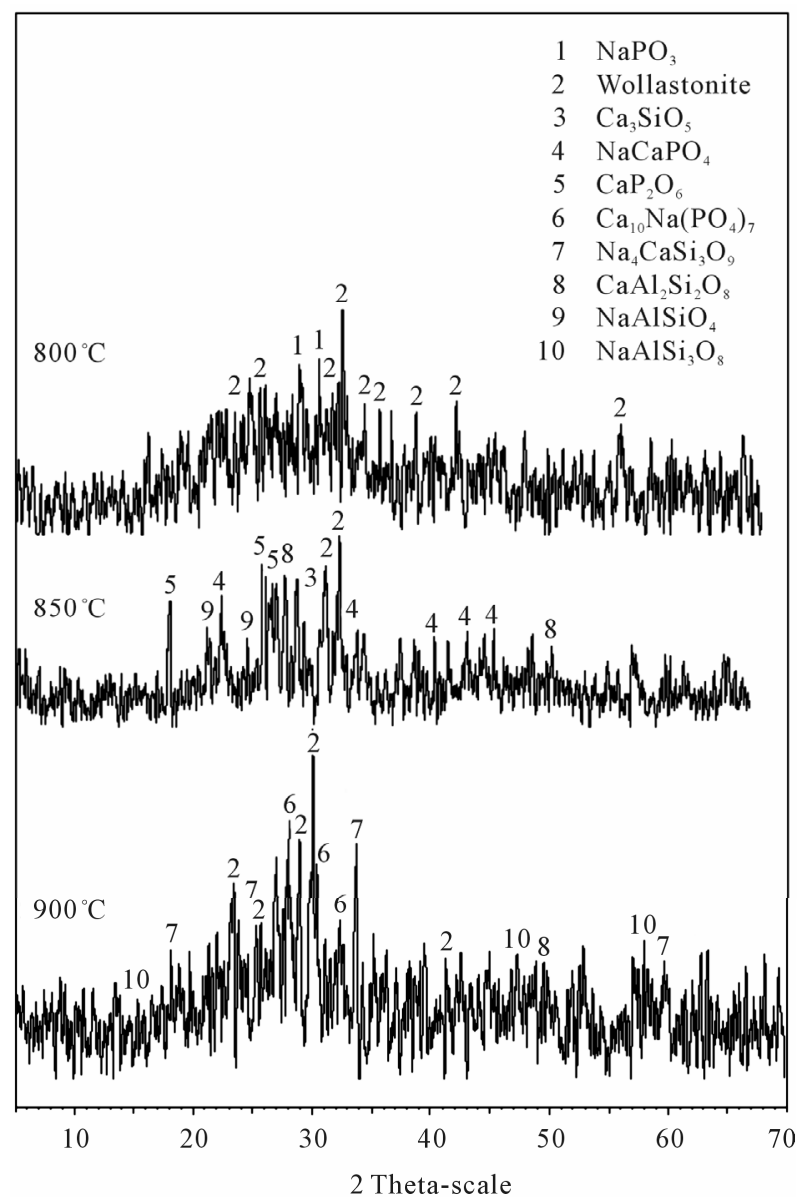

Figure 3. XRD patterns of glass-ceramics G3, after sintering at $800^{\circ} \mathrm{C}, 850^{\circ} \mathrm{C}$ and $900^{\circ} \mathrm{C}$ for $3 \mathrm{~h}$.

Table 3. Crystalline phases in various sample G3.

\begin{tabular}{|c|c|}
\hline $\begin{array}{l}\text { Phases (Sintering } \\
\text { Temperature) }\end{array}$ & Crystalline Phase \\
\hline $800^{\circ} \mathrm{C}$ & $\begin{array}{l}\text { Wollastonite } \mathrm{CaSiO}_{3} \text {-Sodium Phosphate } \\
\mathrm{NaPO}_{3} \text {-Amorphous Phase }\end{array}$ \\
\hline $850^{\circ} \mathrm{C}$ & $\begin{array}{l}\text { Calcium Silicate } \mathrm{Ca}_{3} \mathrm{SiO}_{5} \text {-beta Rhenanite } \\
\beta \text {-NaCaPO} \\
\text { Phosphate } \mathrm{CaP}_{2} \mathrm{O}_{6}, \mathrm{CaAl}_{2} \mathrm{Ci}_{2} \mathrm{O}_{8}, \mathrm{NaAlSiO}_{4} \text {, } \\
\text { Amorphous Phase }\end{array}$ \\
\hline $900^{\circ} \mathrm{C}$ & 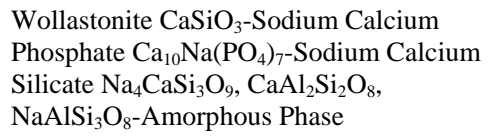 \\
\hline
\end{tabular}

phase at $900^{\circ} \mathrm{C}$. Furthermore, $\mathrm{NaCaPO}_{4}$ crystals were no longer detected. $\mathrm{NaCaPO}_{4}$ crystals dissolved and new crystal phases (Sodium Calcium Phosphate $\mathrm{Ca}_{10} \mathrm{Na}\left(\mathrm{PO}_{4}\right)_{7}$ and Sodium Calcium Silicate $\mathrm{Na}_{4} \mathrm{CaSi}_{3} \mathrm{O}_{9}$ ) formed.

\subsection{Microscopic Examinations}

Figure 4 shows the micrographs of specimen G3 after crystallization at $800^{\circ} \mathrm{C}, 810^{\circ} \mathrm{C}$ (crystallization temperature), $850^{\circ} \mathrm{C}$ and $900^{\circ} \mathrm{C}$ temperatures, taken by SEM. As 

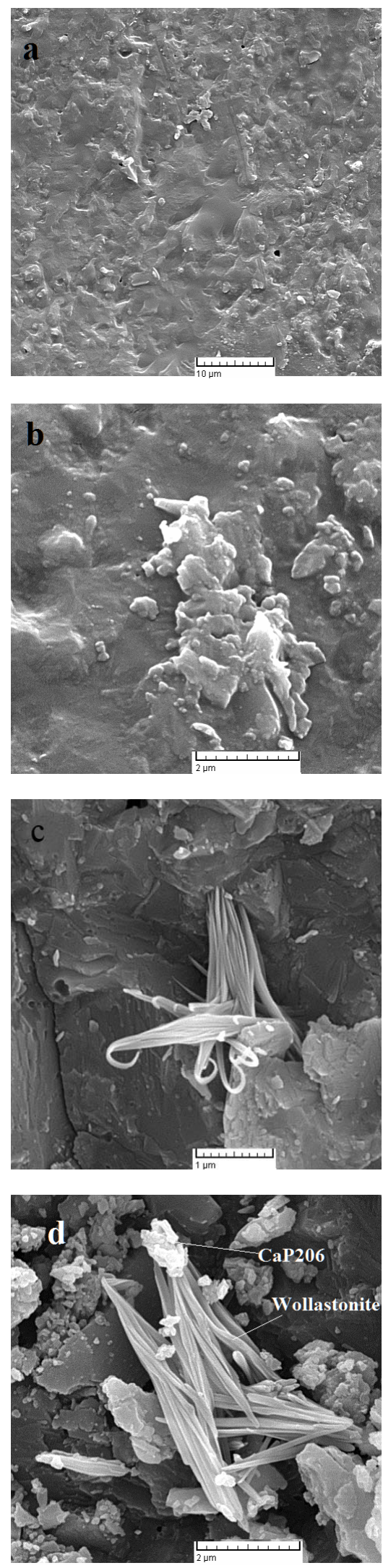

Figure 4. SEM micrographs of crystallized sample G3, sintered at: (a) $800^{\circ} \mathrm{C}$; (b) $810^{\circ} \mathrm{C}$; (c) $850^{\circ} \mathrm{C}$ and (d) $900^{\circ} \mathrm{C}$. sample (b) was sintered at crystallization temperature, it crystallized more than sample (a) as expected and bigger crystallites are formed.

At the higher temperatures at which glasses (c) and (d) were sintered, the conditions for nucleation and growth of a new crystalline phase, i.e. wollastonite, and $\mathrm{CaP}_{2} \mathrm{O}_{6}$, are favorable and microstructures with good crystallinity appear. Figure 4(d) shows wollastonite and $\mathrm{Na}_{4} \mathrm{CaSi}_{3} \mathrm{O}_{9}$ crystals. The EDAX analysis of $\mathrm{G} 3$ sintered at $850^{\circ} \mathrm{C}$ is shown in Figures 5(a), (b). wollastonite, $\mathrm{CaP}_{2} \mathrm{O}_{6}$ are formed in samples $\mathrm{G} 3$ at mentioned sintering temperature. The variations of hardness versus sintering temperature for specimen G3 are shown in Figure 6. It is observed that increasing the temperature of sintering up to $850^{\circ} \mathrm{C}$ results in increasing the hardness and decreasing thereafter with increasing temperature up to $900^{\circ} \mathrm{C}$.

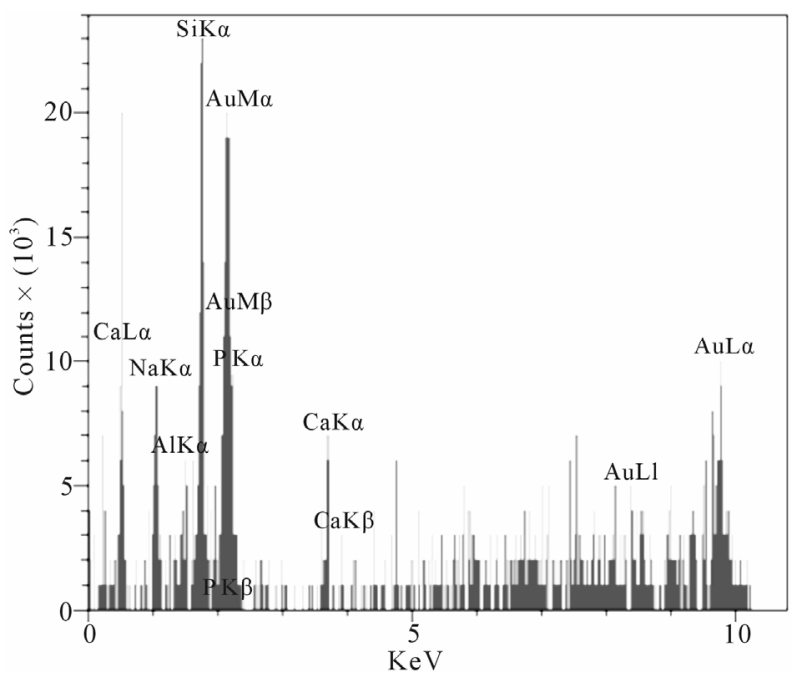

(a)

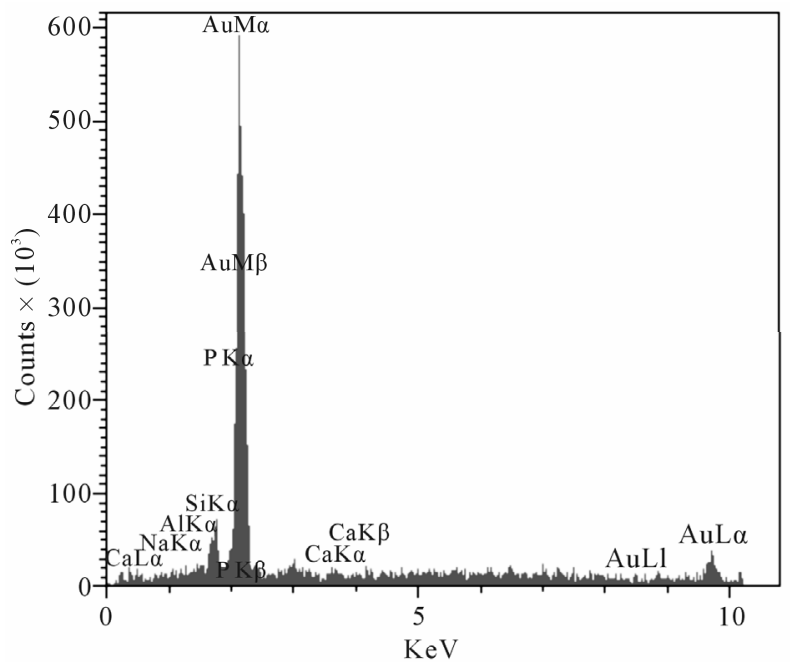

(b)

Figure 5. The EDAX analysis of sample G3: (a) Wollastonite; (b) $\mathrm{CaP}_{2} \mathrm{O}_{6}$. 


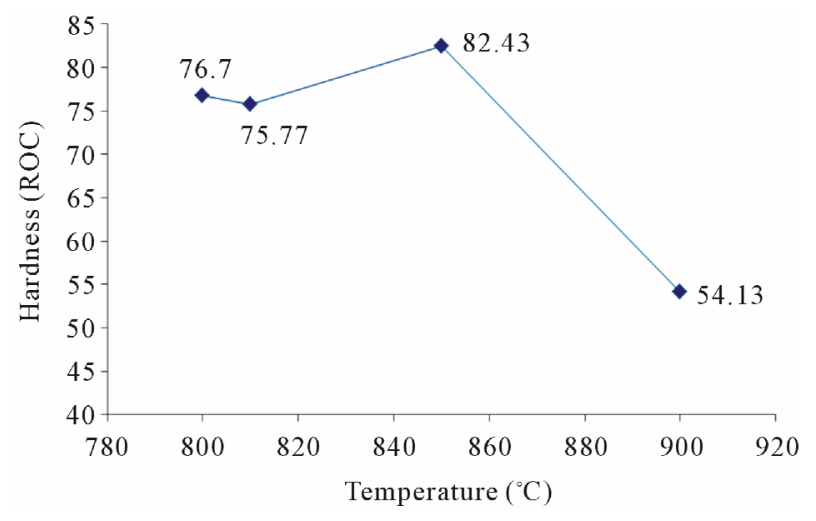

Figure 6. Variations of hardness versus temperature of sintering.

\section{Discussion}

The qualities of a glass-ceramic, however, depend on the kind and quantity of the crystal phase formed, as well as on the residual glass composition. In principle, the kind of crystal phase is related to the parent glass composition, but its quantity depends on the temperature the heat treatment. Therefore, the presence of an efficient nucleating agent in the correct concentration and the determination of the temperature and time of the crystallization and acquire particular importance in the formation of a glass-ceramic. Replacement of $\mathrm{Al}_{2} \mathrm{O}_{3}$ instead $\mathrm{Na}_{2} \mathrm{O}$ cause increase crystallization temperature. Sodium oxide is a network modifier and small changes in its percentage affect significantly the melting temperature of the glass [16]. With the increase of the $\mathrm{Al}_{2} \mathrm{O}_{3}$ content in the $\mathrm{Na}_{2} \mathrm{O}$ $\mathrm{CaO}-\mathrm{P}_{2} \mathrm{O}_{5}-\mathrm{SiO}_{2}$ glasses, crystallization temperature gradually increases (Table 3). The crystal structure of $\beta$-Rhenanite was investigated by Jalota et al. [17]. This crystal phase has a polymorphic transformation from low to high form at approximately $850^{\circ} \mathrm{C}$. Glass ceramics which contained $\mathrm{NaCaPO}_{4}$ as the crystalline phase were also reported to be bioactive [18-20]. Sample G3 sintered at $850^{\circ} \mathrm{C}$ has maximum bending strength because $\mathrm{Ca}_{3} \mathrm{SiO}_{5}$ phase has formed at $850^{\circ} \mathrm{C}$. This phase improves mechanical behavior and has potential biomaterial. With increasing sintering temperature up to $900^{\circ} \mathrm{C}, \mathrm{Ca}_{3} \mathrm{SiO}_{5}$ phase disappeared and reduced bending strength.

\section{Conclusions}

Sintering behavior of $\mathrm{Na}_{2} \mathrm{O}-\mathrm{CaO}-\mathrm{P}_{2} \mathrm{O}_{5}-\mathrm{SiO}_{2}-\mathrm{Al}_{2} \mathrm{O}_{3}$ biological glasses containing different amounts $\mathrm{Al}_{2} \mathrm{O}_{3}$ has been investigated. The results in this study are summarized as follows:

1) Addition of $\mathrm{Al}_{2} \mathrm{O}_{3}$ to glass shifts the crystallisation peak to higher temperature.

2) Addition of alumina to glasses up to $2 \% \mathrm{~mol}$, increases density and hardness of samples.

3) Sample G3 sintered at $850^{\circ} \mathrm{C}$ has maximum bending strength because $\mathrm{Ca}_{3} \mathrm{SiO}_{5}$ phase has formed at $850^{\circ} \mathrm{C}$.

4) The amount of $\mathrm{Al}_{2} \mathrm{O}_{3}$ in the glass ceramics and sintering temperature play an important role in controlling both phase formation and microstructures.

\section{Acknowledgements}

The authors are indebted to ceramic laboratory in instituted standard and research industrial of Iran, which supplied the raw materials for the development of this research and to ceramic department (International University of Iran) for its financial support.

\section{REFERENCES}

[1] L. L. Hench, "Bioceramics," Journal of the American Ceramic Society, Vol. 81, No. 8, 1998, pp. 1705-1728.

[2] W. Donald and J. T. M. Turner, "Antigenicity of FreezeDried Bone Allograft in Periodontal Osseous Defects," Journal of Periodontal Research, Vol. 16, No. 1, 2006, pp. 89-99.

[3] H. Shegarfi, "Review Article: Bone Transplantation and Immune Response,” Journal of Orthopaedic Surgery, Vol. 17, No. 2, 2009, pp. 206-211.

[4] S. F. Hulbert, "Ceramics in Clinical Applications: Past, Present and Future,” In: P. Vincenzini, Ed., High Tech Ceramics, Elsevier, Amsterdam, 1987, pp. 189-213.

[5] E. A. Suominen, J. Juhanoja and A. Yli-Urpo, "Hydroxyapatite-Glass Composite as a Bone Substitute in Large Metaphyseal Cavities in Rabbits," International Orthopaedics, Vol. 19, No. 3, 1995, pp. 167-173.

[6] P. Li, Q. Yang, F. Zhang and T. Kokubo, "The Effect of Residual Glassy Phase in a Bioactive Glass-Ceramic on the Formation on Its Surface Apatite Layer in Vitro," Journal of Materials Science: Materials in Medicine, Vol. 3, No. 6, 1992, pp. 452-456. doi:10.1007/BF00701242

[7] L. L. Hench, "Bonding Mechanisms at the Interface of Ceramic Prosthetic Materials,” Journal of Biomedical Materials Research, Vol. 2, No. 1, 1971, pp. 117-141. doi:10.1002/jbm.820050611

[8] I. D. Thompson and L. L. Hench, "Mechanical Properties of Bioactive Glasses, Glass-Ceramics and Composites," Proceedings of the Institution of Mechanical Engineers, Part H: Journal of Engineering in Medicine, Vol. 212, No. 2, 1998, pp. 127-136. doi:10.1243/0954411981533908

[9] F. H. Lin and M. H. Hon, "A Study on Bioglass Ceramics in the $\mathrm{Na}_{2} \mathrm{O}-\mathrm{CaO}-\mathrm{SiO}_{2}-\mathrm{P}_{2} \mathrm{O}_{5}$ System," Journal of Materials Science, Vol. 23, No. 12, 1988, pp. 4295-4299. doi:10.1007/BF00551922

[10] P. N. De Aza and Z. B. Luklinska, "Effect of Glass-Ceramic Microstructure on Its in Vitro Bioactivity,” Journal of Materials Science, Vol. 14, No. 10, 2003, pp. 891-898. doi:10.1023/A:1025686727291

[11] A. El-Ghannam, E. Hamazawy and A. Yehia, "Effect of Thermal Treatment on Bioactive Glass Microstructure, Corrosion Behavior, Zeta Potential, and Protein Adsorption,” 
Journal of Biomedical Materials Research, Vol. 55, No. 3, 2001, pp. 387-395. doi:10.1002/1097-4636(20010605)55:3<387::AID-JBM1 $\underline{027>3.0 . C O ; 2-\mathrm{V}}$

[12] T. Kokubo, M. Shigematsu and Y. Nagashima, "Apatite and Wollastonite Containing Glass-Ceramics for Prosthetic Application,” Bulletin of the Institute for Chemical Research, Kyoto University, Vol. 60, 1982, pp. 260-268.

[13] T. Kasuga, K. Nakagawa, M. Yoshida and E. Miyade, "Compositional Dependence of Formation of an Apatite Layer on Glass-Ceramic in Simulated Physiological Solution,” Journal of Materials Science, Vol. 22, No. 10, 1987, pp. 3721-3724. doi:10.1007/BF01161484

[14] J. J. Shyu and J. M. Wu, "Effects of Compositional Changes on the Crystallization Behavior of MgO-CaO$\mathrm{SiO}_{2}-\mathrm{P}_{2} \mathrm{O}_{5}$ Glass-Ceramics," Journal of the American Ceramic Society, Vol. 74, No. 9, 1991, pp. 2123-2130. doi:10.1111/j.1151-2916.1991.tb08270.x

[15] K. Kangasniemi and A. Yli-Urpo, "Handbook of Bioactive Ceramics, Bioactive Glasses and Glass-Ceramics, Vol. 1,” In: J. Wilson, Ed., CRC Press, Boston, 1990.

[16] D. U. Tulyaganov and S. Agathopoulos, "Synthesis, Bioactivity and Preliminary Biocompatibility Studies of Glasses in the System $\mathrm{CaO}-\mathrm{MgO}-\mathrm{SiO}_{2}-\mathrm{Na}_{2} \mathrm{O}-\mathrm{P}_{2} \mathrm{O}_{5}-\mathrm{CaF}_{2}$," Journal of Materials Science: Materials in Medicine, Vol. 22, No. 2, 2011, pp. 217-227. doi:10.1007/s10856-010-4203-5

[17] S. Jalota, S. B. Bhaduri and A. C. Tas, “A New Rhenanite $\left(\beta-\mathrm{NaCaPO}_{4}\right)$ and Hydroxyapatite Biphasic Biomaterial for Skeletal Repair,” Journal of Biomedical Materials Research Part B: Applied Biomaterials, Vol. 80, No. 2, 2006, pp. 304-316.

[18] W. Gong, A. Abdelouas and W. Lutze, "Porous Bioactive Glass and Glass-Ceramics Made by Reaction Sintering under Pressure,” Journal of Biomedical Materials Research, Vol. 54, No. 3, 2001, pp. 320-327. doi:10.1002/1097-4636(20010305)54:3<320::AID-JBM2 $\underline{0>3.3 . C O ; 2-5}$

[19] E. A. Ghannam, “Advanced Bioceramic Composite for Bone Tissue Engineering: Design Principles and Structure-Bioactivity Relationship,” Journal of Biomedical Materials Research, Vol. 69, No. 3, 2004, pp. 490-501.

[20] E. Metwalli and R. K. Brow, "Cation Effects on Anion Distributions in Aluminophosphate Glasses,” Journal of the American Ceramic Society, Vol. 84, No. 5, 2001, pp. 1025-1032. doi:10.1111/j.1151-2916.2001.tb00785.x 